\title{
Colombian health care system: results on equity for five health dimensions, 2003-2008
}

\author{
Fernando Ruiz Gómez, ${ }^{1}$ Teana Zapata Jaramillo, ${ }^{2}$ \\ and Liz Garavito Beltrán ${ }^{3}$
}

ABSTRACT Objective. To assess the change in five health equity dimensions for the Colombian health system: health condition, social health insurance coverage, health services utilization, quality, and health expenditure.

Methods. A common standardization methodology was used to assess equity in countries in the western hemisphere. Data come from the Colombian Life Quality Survey. After indirect standardization, concentration indices and horizontal inequity were estimated. A decomposition analysis was developed. Aggregate household monthly expenditure per equivalent adult was considered as the standard of living.

Results. Results show important progress in equity with regard to social health insurance affiliation, access to medicine and curative services, and perception of the quality of health care service. Important gaps persist, which affect poorer populations, especially their perception of having a bad health condition and their access to preventive medical and dental services.

Conclusions. The Colombian model needs to advance in implementing preventive public health strategies to cope with increasing demand concomitant with increased social insurance coverage. The population's access to total services in cases of chronic illness and oral health services must increase and benefit plans must be integrated while preserving the recorded achievements in equity. Decomposition of the concentration index shows that inequities are mostly explained by socioeconomic variables and not by health-related factors.

Key words Equity in health; health systems; equity in access; health economics; health policy; Colombia.

The Colombian reform in 1993 led to implementation of a social health insurance scheme with two objectives: expansion of coverage through universal health insurance as the previous segmented scheme covered only $15.7 \%$

\footnotetext{
1 Ministerio de Salud y Protección Social, Viceministerio de Salud y Prestación de Servicios, Bogotá, Colombia. Send correspondence to: Fernando Ruiz Gómez, fruiz@minsalud.gov.co

2 Pontificia Universidad Javeriana, Centro de Proyectos para el Desarrollo, Cendex, Bogotá, Colombia.

3 Processum Consultoria Institucional SAS, Bogotá, Colombia.
}

of the population (1), who were the wealthiest and employed in the formal sector of the economy, and harmonization of health care benefits focusing on poor populations, subsidizing demand, and explicitly guaranteeing a benefit plan. Addressing inequity was the goal. Before the reform, health inequity was prominent. Although $84.3 \%$ of medical needs were addressed in the wealthiest economic quintile, only $16 \%$ were addressed in the poorest quintile (2). The financing mechanism was based on crossed-subsidy social security pay- ments whereby people with higher incomes subsidized poorer populations, and the national government provided a contribution of equal size through budget reserves. A radical change in the system was needed so the health reform was introduced. Changes include expansion of social health insurance (contributory and subsidized), a benefit package with warranty of coverage, and integration of public and private providers in a regulated competition scheme seeking to increase efficiency in delivery of health services. 
According to Garavito (3), $88.2 \%$ of the Colombian population is now insured. Growth in coverage was achieved through expansion from individual to family coverage in the contributory scheme and affiliation of the lower-income population through the subsidized regimen. Expansion in the subsidized policy from 2003 to 2007 is responsible for the greatest part of the growth in coverage.

Evidence on the impact of the Colombian reform on equity is scarce and contradictory. One study found no positive impacts from health reforms in Brazil and Colombia with regard to life expectancy and three mortality indicators from assessing trends in the period 1960-2005 (4). Most Colombian health reform evaluations have focused on measuring the progress in access to health service and financial protection attained by the poorest segment of the population. Another study found that social health insurance in its initial stage had increased the use of medical services as a consequence of the progressive accumulation of better health conditions and coverage for chronic illness (5). A prospective cohort study evidenced advances in access to service for the insured poor population (6) and greater out-of-pocket expenditure among the noninsured population (7). An econometric analysis based on the living standards survey showed an increase in use by the subsidized population and in protection against financial shocks among vulnerable populations: residents in rural areas, independent workers, and people in conditions of extreme poverty (8). The one-year follow-up of Bogota's population estimated fairly low $(4.9 \%)$ health-related catastrophic expenditures (9). Two recent studies on the determinants of affiliation and effective consumption of social health insurance showed important differences in the likelihood of being insured, access to services, and intensity of health care service use between the urban and the rural populations and better access and consumption for populations with chronic illnesses such as high blood pressure, tuberculosis, and cancer (10). Furthermore, greater access to services for persons with specific pathologies, such as diabetes, has been documented (11). The main criticisms of the health system are directed toward bad socioeconomic classification affecting the poorer populations (12), low service coverage for the poorer populations (13), the potentially regressive nature of out-of-pocket expenditure due to the copayment system (14), and inefficient access to service for the more vulnerable populations (15). However, most of these studies are on care, with low representativeness, and they do not address changes over time (16).

Equity attainments on access, quality, and families' out-of-pocket expenditure would justify the society investment and radical institutional changes implemented by the health reform. This attainment has not been measured on a timeline basis and has not been related to socioeconomic status and the health needs of the population. The results in equity maybe an effective way to measure outcomes in the Colombian system and to drive future regulations once universal coverage is attained.

The available evidence has limitations due to the lack of baselines, standardized longitudinal evaluations, and low representativeness. The absence of robust equity analysis is an additional problem as most studies present evidence on partial effects or case studies with limited statistical power. Recent studies on equity have contributed statistical evidence for strong evaluations of the health situation in different countries $(17,18)$.

This study seeks to assess the Colombian health system's progress in equity by means of a standardization methodology and by using representative population surveys of living conditions. The objective is to weigh variations in selected health variables and access to services among different population groups based on their standards of living. The analysis looks at changes in health variables from 2003 to 2008 . The link between these changes in the health system and progress in health is an indirect measure of performance of the Colombian health system.

\section{MATERIALS AND METHODS}

A longitudinal trend study was carried out that compares indicators of health inequality from 2003 to 2008 as cut points. The unit of analysis is the individual. All adults 18 years of age or older are included. A general methodology paper from the multicountry study developed under the Equilac II Project is provided in this issue (19). The methodologic framework adopted was developed by O'Donnell et al. (20). Data from the Life Quality Survey (Encuesta de Calidad de Vida) were used, given their representativeness and standardization. This survey has been conducted by the Colombian National Statistics Department [Departamento Administrativo Nacional de Estadística (DANE)] since 1993. It contains information about socioeconomic conditions and access to social services. It became evident from a review of the macro-data from the 1993 and 1997 surveys that there were differences in accumulated expenditure and revenue and restrictions in age groups for access to health care service variables. Therefore, the analysis was done using the more homogenous 2003 and 2008 surveys. The Life Quality Survey data are representative for the national, urban, and rural populations as well as for nine regions: Bogotá, Antioquia, Valle del Cauca, Atlántico, Oriental, Central, Pacífica, the San Andrés and Providencia islands, and Orinoquía, Amazonía, and Putumayo. The last three areas are integrated in a single region. The information was analyzed with the Stata 11.0 program. To consolidate a household's accumulated expenditure and enable comparison with other national studies, the methodology used to aggregate and weigh the different expenditure headings was developed by the Colombian National Planning Department (Departamento Nacional de Planeación) and by DANE.

Health sector variables were grouped as follows (Table 1): health status, health care utilization, social health insurance, health service quality, and health expenditures. Variables are described in Table 1.

The method includes a description of the 2003-2008 changes for health indicator classified in five health dimensions: health status, health care utilization, social health insurance, health service quality, and health expenditure. Monthly household expenditure per equivalent adult was used as the socioeconomic variable. Unstandardized and standardized indices and curves were estimated. Decompositions between need (health) and non-need (socioeconomic and other factors) conditions were also incorporated.

\section{RESULTS}

The set of analysis variables encompasses different dimensions of health equity in the population. Table 2 presents the descriptive results with means, 
TABLE 1. Description of health variables, Colombia, 2003 and 2008

\begin{tabular}{|c|c|}
\hline Variable & Description \\
\hline \multicolumn{2}{|l|}{ Health status } \\
\hline Less than good health status & Categorical: how do you describe your general health status? 0: very good or good, 1: less than good. \\
\hline Presence of chronic illness & Categorical: do you have any chronic disease (hypertension, diabetes, etc.)? 1: yes, 0: no. \\
\hline Number of days of sick leave & $\begin{array}{l}\text { Numeric count: how many days did you stop doing your normal activities due to health problems (illness, } \\
\text { accident, dental problems, or other health problem in past } 30 \text { days that has not involved inpatient events)? }\end{array}$ \\
\hline \multicolumn{2}{|l|}{ Health care utilization } \\
\hline Any preventive physician visit & Categorical: without being sick or for prevention, at least once a year get checked by a doctor: 1: yes, 0 : no. \\
\hline Any preventive dentist visit & Categorical: without being sick or for prevention, at least once a year get checked by a dentist: $1:$ yes, $0:$ no. \\
\hline Any curative visit & $\begin{array}{l}\text { Categorical: to address health problem in past } 30 \text { days (illness, accident, dental problems, or other health } \\
\text { problem that has not involved inpatient events). Did you visit a general practitioner, specialist, homeopath, } \\
\text { acupuncturist, dentist, therapist, or health institution? 1: yes, 0: no. }\end{array}$ \\
\hline Any referral or visit to a specialist & $\begin{array}{l}\text { Categorical: to address health problem in past } 30 \text { days (illness, accident, dental problems, or other health } \\
\text { problem that has not involved inpatient events). Were you referred or appealed to a specialist? } 1: \text { yes, } 0: \text { no. }\end{array}$ \\
\hline Any hospitalization & Categorical: have you been an inpatient during past 12 months? 1: yes, 0 : no. \\
\hline \multicolumn{2}{|l|}{ Social health insurance } \\
\hline Social health insurance coverage & Categorical: are you affiliated with some social health insurance entity? 1: yes, 0: no. \\
\hline Rural insurance coverage & Categorical: are you affiliated with some social health insurance entity? 1: yes, 0: no. \\
\hline Urban insurance coverage & Categorical: are you affiliated with some social health insurance entity? 1: yes, 0: no. \\
\hline Contributive plan affiliation & Categorical: are you affiliated with contributory insurance? 1: yes, 0: no. \\
\hline Subsidized plan affiliation & Categorical: are you affiliated with subsidized insurance? 1: yes, 0 : no. \\
\hline \multicolumn{2}{|l|}{ Health service quality } \\
\hline $\begin{array}{l}\text { Perceived service quality of general practitioner or } \\
\text { specialist (less than good) }\end{array}$ & Categorical: in general terms, do you think service quality was: 0: good, 1 : less than good. \\
\hline Perceived hospital service quality (less than good) & Categorical: do you believe the quality of hospital service was: $0:$ good, 1 : less than good. \\
\hline Total or partial medicine supply & $\begin{array}{l}\text { Categorical: in past } 30 \text { days, what medicine prescribed due to health problems (illness, accident, dental } \\
\text { problems, or other health problem that has not involved inpatient events) was given on behalf of the institution } \\
\text { with which you are affiliated? }\end{array}$ \\
\hline Waiting days: medical or dental visit & $\begin{array}{l}\text { Numeric count: how many days elapsed between the time to make the appointment and the time of consultation } \\
\text { with general practitioner or dentist? }\end{array}$ \\
\hline Waiting days: specialist visit & $\begin{array}{l}\text { Numeric count: how many days elapsed between the time to make the appointment and the time of consultation } \\
\text { with specialist? }\end{array}$ \\
\hline \multicolumn{2}{|r|}{ 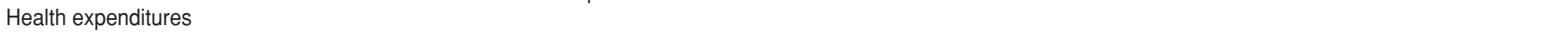 } \\
\hline Contributions to social health insurance & $\begin{array}{l}\text { Continuous: how much do you pay or are discounted monthly to be covered by a health social security } \\
\text { institution? }\end{array}$ \\
\hline $\begin{array}{l}\text { Outpatient out-of-pocket expenditure, specific } \\
\text { health problem }\end{array}$ & $\begin{array}{l}\text { Continuous: how much did you pay in total for health care (medical consultation, tests, and medicine) due } \\
\text { to health problems in past } 30 \text { days (illness, accident, dental problems, or other health problem that has not } \\
\text { involved inpatient events)? }\end{array}$ \\
\hline Inpatient out-of-pocket expenditure & $\begin{array}{l}\text { Continuous: how much did you pay in total for hospitalizations in past year (medical consultation, tests, and } \\
\text { medicine)? }\end{array}$ \\
\hline Aggregated out-of-pocket expenditure on health & $\begin{array}{l}\text { Continous: includes monthly expenditure on cotton, gauze, disinfectant, alcohol, bandages, contraceptives, } \\
\text { aspirin, other items of medical kit, medical formulas, or purchase of drugs consumed regularly, last payment of } \\
\text { health care for health problems in past month, full payment for hospitalization if hospitalized in past year, and } \\
\text { monthly payments or discounts by plans or complementary health insurance. }\end{array}$ \\
\hline \multicolumn{2}{|r|}{ (2) } \\
\hline Expenditure & Continuous: household expenditure per equivalent adult. \\
\hline \multicolumn{2}{|r|}{. } \\
\hline Age and sex & Categorical: six age and sex categories for males and females in age groups $18-44,45-59,60$ or older \\
\hline Geographic region & Categorical: Atlántica, Oriental, Central, Pacifica, Bogotá, Antioquia, Valle, San Andrés, Orinoquía, Amazonía. \\
\hline Area of residence & Categorical: urban, rural. \\
\hline Economic activity & $\begin{array}{l}\text { Categorical: employed, unemployed, economically inactive population with working capacity, economically } \\
\text { inactive population without working capacity. }\end{array}$ \\
\hline Occupation type & $\begin{array}{l}\text { Categorical: private company or government employee, day laborer, domestic employee, independent, } \\
\text { employer, unpaid worker or helper. }\end{array}$ \\
\hline Sector worker & Categorical: formal, informal. \\
\hline Education & $\begin{array}{l}\text { Categorical: highest level of education attained. None, elementary or primary, high school or secondary, } \\
\text { graduate degree, postgraduate degree. }\end{array}$ \\
\hline Marital status & Married, single, divorced, widowed, cohabit. \\
\hline Private health insurance & Categorical: yes/no. \\
\hline Health insurance & Categorical: unaffiliated, contributive plan affiliation, subsidized plan affiliation, special plan affiliation, other. \\
\hline Socioeconomic stratum & Categorical: 1, 2, 3, 4, 5, 6 . \\
\hline
\end{tabular}

standard deviations, and differences of means for the measurements in 2003 and 2008. A 95\% confidence interval for the mean is provided; $t$-tests for the mean difference between 2008 and 2003 were also performed.
The descriptive results show slight changes in health conditions during the analyzed period. Outcomes for health status and presence of chronic illness improved and differ from the increase found in the number of sick leave days for 2008. Social insurance coverage reported a significant growth of $23 \%$. Most of this growth can be attributed to a subsidized plan expansion that produced a displacement on the relative share of the contributive regimen in overall social 
TABLE 2. Descriptive statistics for health variables, Life Quality Survey, Colombia, 2003 and 2008

\begin{tabular}{|c|c|c|c|c|c|c|c|}
\hline & \multicolumn{3}{|c|}{2003} & \multicolumn{3}{|c|}{2008} & \multirow{2}{*}{$\begin{array}{c}\text { Mean difference } \\
\text { [mean (2008) - } \\
\text { mean (2003)] }\end{array}$} \\
\hline & Mean & $\begin{array}{l}\text { Standard } \\
\text { deviation }\end{array}$ & $\begin{array}{l}\text { 95\% confidence } \\
\text { interval }\end{array}$ & Mean & $\begin{array}{l}\text { Standard } \\
\text { deviation }\end{array}$ & $\begin{array}{l}95 \% \text { confidence } \\
\text { interval }\end{array}$ & \\
\hline \multicolumn{8}{|l|}{ Health condition } \\
\hline Less than good health status & 0.34 & 0.48 & $0.34-0.35$ & 0.29 & 0.45 & $0.28-0.29$ & $-0.05^{a}$ \\
\hline Presence of chronic illness & 0.19 & 0.39 & $0.18-0.19$ & 0.15 & 0.36 & $0.15-0.16$ & $-0.04^{a}$ \\
\hline Days of sick leave & 5.16 & 10.79 & $4.88-5.44$ & 6.20 & 14.70 & $5.79-6.62$ & $1.04^{\mathrm{a}}$ \\
\hline \multicolumn{8}{|l|}{ Social health insurance } \\
\hline Social health insurance coverage & 0.64 & 0.48 & $0.63-0.64$ & 0.87 & 0.34 & $0.86-0.87$ & $0.23^{a}$ \\
\hline Rural insurance coverage & 0.55 & 0.50 & $0.54-0.56$ & 0.85 & 0.35 & $0.85-0.86$ & $0.30^{\mathrm{a}}$ \\
\hline Urban insurance coverage & 0.67 & 0.47 & $0.66-0.67$ & 0.87 & 0.34 & $0.86-0.87$ & $0.20^{\mathrm{a}}$ \\
\hline Contributive plan affiliation & 0.60 & 0.49 & $0.60-0.61$ & 0.49 & 0.50 & $0.48-0.50$ & $-0.11^{\mathrm{a}}$ \\
\hline Subsidized plan affiliation & 0.34 & 0.47 & $0.33-0.34$ & 0.47 & 0.50 & $0.47-0.48$ & $0.13^{a}$ \\
\hline \multicolumn{8}{|l|}{ Health service use } \\
\hline Any preventive physician visit & 0.47 & 0.50 & $0.47-0.48$ & 0.54 & 0.50 & $0.53-0.54$ & $0.07^{a}$ \\
\hline Any preventive dentist visit & 0.32 & 0.47 & $0.32-0.32$ & 0.35 & 0.48 & $0.34-0.35$ & $0.03^{a}$ \\
\hline Any curative visit & 0.69 & 0.46 & $0.67-0.70$ & 0.78 & 0.41 & $0.77-0.80$ & $0.09^{a}$ \\
\hline Any referral or visit to specialist & 0.31 & 0.46 & $0.29-0.32$ & 0.34 & 0.47 & $0.33-0.36$ & $0.03^{a}$ \\
\hline Any hospitalization & 0.08 & 0.27 & $0.08-0.08$ & 0.07 & 0.26 & $0.07-0.08$ & -0.01 \\
\hline \multicolumn{8}{|l|}{ Health service quality } \\
\hline $\begin{array}{l}\text { Perceived service quality of general practitioner or } \\
\text { specialist (less than good) }\end{array}$ & 0.23 & 0.42 & $0.22-0.24$ & 0.23 & 0.42 & $0.22-0.25$ & 0.0 \\
\hline Perceived hospital service quality (less than good) & 0.18 & 0.39 & $0.17-0.20$ & 0.17 & 0.38 & $0.16-0.19$ & $-0.01^{b}$ \\
\hline Total or partial medicine supply & 0.53 & 0.50 & $0.51-0.54$ & 0.75 & 0.44 & $0.73-0.76$ & $0.22^{a}$ \\
\hline Waiting days: medical or dental visit & 1.96 & 4.69 & $1.81-2.11$ & 3.09 & 6.07 & $2.89-3.28$ & 1.13 \\
\hline Waiting days: specialist visit & 10.94 & 21.04 & $9.88-12.01$ & 12.55 & 19.73 & $11.45-13.66$ & $1.61^{\mathrm{a}}$ \\
\hline \multicolumn{8}{|l|}{$\begin{array}{l}\text { Health expenditure deflated by CPI } 2010 \\
\text { (NEER } 2010=\$ 1897.89 \text { per U.S. dollar) }\end{array}$} \\
\hline $\begin{array}{l}\text { Contribution to social health insurance per month } \\
\text { (U.S. dollars) }\end{array}$ & 36.15 & 39.81 & $35.54-36.76$ & 36.89 & 43.33 & $35.85-37.93$ & $0.74^{a}$ \\
\hline $\begin{array}{l}\text { Outpatient out-of-pocket expenditure for specific } \\
\text { health problem per month (U.S. dollars) }\end{array}$ & 28.16 & 123.38 & $24.74-31.58$ & 13.11 & 66.36 & $11.01-15.21$ & $-15.05^{a}$ \\
\hline $\begin{array}{l}\text { Inpatient out-of-pocket expenditure per year } \\
\text { (U.S. dollars) }\end{array}$ & 136.93 & 481.23 & $122.39-151.47$ & 68.68 & 328.49 & $55.45-81.92$ & $-68.25^{a}$ \\
\hline $\begin{array}{l}\text { Aggregated out-of-pocket expenditure on health } \\
\text { per month (U.S. dollars) }\end{array}$ & 17.34 & 165.02 & $15.97-18.72$ & 10.47 & 98.97 & $9.38-11.56$ & $-6.87^{a}$ \\
\hline
\end{tabular}

Source: Life Quality Survey, 2003 and 2008.

$\mathrm{CPI}$ : consumer price index, NEER: normal effective exchange rate.

a $P<0.01$.

b $P<0.05$.

insurance coverage. A striking result is the increase in urban and rural insurance coverage with an $11 \%$ increase in rural insurance above the expansion rate reported in terms of urban insurance enrollment. These results are attributable to subsidized insurance, as the contributive insurance did not report an increase during that period $(P<0.01)$.

An important aspect of social insurance equity worth considering is that insurance coverage leads to changes in access to health services. The study results indicate significant increases in preventive and curative outpatient services. However, access to preventive oral health services is fairly low. The rates of inpatient services are quite high and show no significant changes during the period analyzed.

Quality results indicate a downward trend in the opportunity indicators, particularly waiting days for consultation with a specialist $(P<0.01)$. However, the average $22 \%$ increase in the total or partial supply of medicine is a significant outcome of the quality of service delivery, assuming that the medicines provided are medically necessary. This result could be highly related to social insurance coverage given the insurer's liability under the law for delivering medications. Contributive and subsidized health plans include guarantees for medicines through a list of medications. Health delivery services in the safety net do not include a guarantee.

The monetary results for out-of-pocket expenses are presented in constant prices (U.S. dollars) adjusted to 2010. Contributions for health insurance coverage refer mainly to the worker population's monthly payroll payments for the contributive regimen enrollment. The change in the cash contribution load (less than \$1) reported during the period is slight but statistically significant. However, an impressive $53 \%$ reduction was evidenced in out-of-pocket expenditures for outpatient services. Similarly, out-of-pocket expenditures for inpatient services declined by $50 \%$. The population average monthly out-of-pocket expenditure dropped $39.6 \%$ between 2003 and 2008. These results are significant at the $99 \%$ level.

Table 3 presents the distribution of each health outcome variable by the population classified according to socioeconomic quintile, from the poorest $20 \%$ to the richest $20 \%$. Table 4 presents inequity outcomes across the population measured by the concentration index (CI) and the horizontal inequity index (HI); the curves are provided in supplementary material.

The results on health condition variables show inequality for the poor in the perception of bad health. The HI for the number of days of sick leave is not statistically significant, which means distribution across socioeconomic quintiles 
TABLE 3. Mean and standardized distribution by quintile, Colombia, 2003 and 2008

\begin{tabular}{|c|c|c|c|c|c|c|c|}
\hline Variable & Year & Mean & Poorest 20\% & 2nd poorest $20 \%$ & Middle & 2nd richest $20 \%$ & Richest $20 \%$ \\
\hline \multicolumn{8}{|l|}{ Health condition } \\
\hline \multirow[t]{2}{*}{ Less than good health status } & 2003 & 0.3441 & 0.4724 & 0.4098 & 0.3588 & 0.2908 & 0.1889 \\
\hline & 2008 & 0.2867 & 0.3906 & 0.3468 & 0.3030 & 0.2320 & 0.1613 \\
\hline \multirow[t]{2}{*}{ Presence of chronic illness } & 2003 & 0.1855 & 0.1685 & 0.1777 & 0.2014 & 0.1925 & 0.1872 \\
\hline & 2008 & 0.1520 & 0.1300 & 0.1450 & 0.1603 & 0.1571 & 0.1676 \\
\hline \multirow[t]{2}{*}{ Days of sick leave } & 2003 & 5.1586 & 4.9948 & 5.9787 & 4.7888 & 5.2178 & 4.8239 \\
\hline & 2008 & 6.2045 & 6.3830 & 7.0804 & 5.3137 & 6.5093 & 5.7665 \\
\hline \multicolumn{8}{|l|}{ Social health insurance } \\
\hline \multirow[t]{2}{*}{ Social health insurance coverage } & 2003 & 0.6378 & 0.5196 & 0.5663 & 0.6033 & 0.6845 & 0.8154 \\
\hline & 2008 & 0.8654 & 0.8395 & 0.8388 & 0.8547 & 0.8816 & 0.9124 \\
\hline \multirow[t]{2}{*}{ Rural insurance coverage } & 2003 & 0.5459 & 0.5367 & 0.5354 & 0.5430 & 0.5630 & 0.6649 \\
\hline & 2008 & 0.8528 & 0.8460 & 0.8664 & 0.8576 & 0.8374 & 0.8507 \\
\hline \multirow[t]{2}{*}{ Urban insurance coverage } & 2003 & 0.6666 & 0.4958 & 0.5784 & 0.6186 & 0.7040 & 0.8257 \\
\hline & 2008 & 0.8689 & 0.8311 & 0.8266 & 0.8543 & 0.8872 & 0.9158 \\
\hline \multirow[t]{2}{*}{ Contributive plan affiliation } & 2003 & 0.6010 & 0.1598 & 0.4147 & 0.6263 & 0.7712 & 0.8461 \\
\hline & 2008 & 0.4908 & 0.1132 & 0.2866 & 0.5018 & 0.6893 & 0.8217 \\
\hline \multirow[t]{2}{*}{ Subsidized plan affiliation } & 2003 & 0.3367 & 0.8307 & 0.5629 & 0.3204 & 0.1485 & 0.0393 \\
\hline & 2008 & 0.4715 & 0.8793 & 0.6963 & 0.4718 & 0.2552 & 0.1004 \\
\hline \multicolumn{8}{|l|}{ Health service use } \\
\hline \multirow[t]{2}{*}{ Any preventive physician visit } & 2003 & 0.4711 & 0.3214 & 0.3935 & 0.4464 & 0.5355 & 0.6588 \\
\hline & 2008 & 0.5380 & 0.4145 & 0.4925 & 0.5494 & 0.5803 & 0.6533 \\
\hline \multirow[t]{2}{*}{ Any preventive dentist visit } & 2003 & 0.3195 & 0.1340 & 0.2189 & 0.2960 & 0.3836 & 0.5650 \\
\hline & 2008 & 0.3482 & 0.1764 & 0.2552 & 0.3430 & 0.4195 & 0.5469 \\
\hline \multirow[t]{2}{*}{ Any curative visit } & 2003 & 0.6859 & 0.6046 & 0.6395 & 0.6464 & 0.7193 & 0.8033 \\
\hline & 2008 & 0.7847 & 0.6949 & 0.7751 & 0.7801 & 0.8299 & 0.8404 \\
\hline \multirow[t]{2}{*}{ Any referral or visit to a specialist } & 2003 & 0.3084 & 0.1784 & 0.2258 & 0.3222 & 0.3227 & 0.4268 \\
\hline & 2008 & 0.3429 & 0.2330 & 0.3205 & 0.3337 & 0.3759 & 0.4283 \\
\hline \multirow[t]{2}{*}{ Any hospitalization } & 2003 & 0.0784 & 0.0628 & 0.0728 & 0.0810 & 0.0808 & 0.0948 \\
\hline & 2008 & 0.0747 & 0.0684 & 0.0752 & 0.0657 & 0.0845 & 0.0798 \\
\hline \multicolumn{8}{|l|}{ Hospital service quality } \\
\hline \multirow{2}{*}{$\begin{array}{l}\text { Perceived service quality of general practitioner } \\
\text { or specialist (less than good) }\end{array}$} & 2003 & 0.2292 & 0.2115 & 0.2154 & 0.2599 & 0.2319 & 0.2202 \\
\hline & 2008 & 0.2325 & 0.2008 & 0.2132 & 0.2224 & 0.2481 & 0.2706 \\
\hline \multirow{2}{*}{$\begin{array}{l}\text { Perceived hospital service quality (less than } \\
\text { good) }\end{array}$} & 2003 & 0.1849 & 0.2660 & 0.1660 & 0.1645 & 0.1723 & 0.1694 \\
\hline & 2008 & 0.1723 & 0.1454 & 0.1884 & 0.1419 & 0.1758 & 0.2069 \\
\hline \multirow[t]{2}{*}{ Total or partial medicine supply } & 2003 & 0.5289 & 0.5513 & 0.4501 & 0.5326 & 0.5349 & 0.5735 \\
\hline & 2008 & 0.7464 & 0.7644 & 0.7410 & 0.7597 & 0.7260 & 0.7441 \\
\hline Waiting days: medical or dental visit & 2003 & 1.9621 & 1.2215 & 1.6408 & 1.7498 & 2.3162 & 2.5711 \\
\hline & 2008 & 3.0853 & 2.1091 & 2.9608 & 3.5956 & 3.2859 & 3.2661 \\
\hline Waiting days: specialist visit & 2003 & 10.9442 & 12.8396 & 13.8968 & 13.2735 & 9.9250 & 8.1973 \\
\hline & 2008 & 12.5544 & 10.1421 & 11.8496 & 12.0511 & 10.5573 & 16.5821 \\
\hline $\begin{array}{l}\text { Health expenditure deflated by CPI } 2010 \\
\text { (NEER } 2010=1897.89 \text { per U.S. dollar) }\end{array}$ & & & & & & & \\
\hline Contribution to social health insurance per month & 2003 & 36.15 & 18.40 & 22.57 & 24.72 & 29.99 & 50.54 \\
\hline (U.S. dollars) & 2008 & 36.89 & 18.65 & 21.11 & 24.55 & 29.45 & 53.60 \\
\hline Outpatient out-of-pocket expenditure for specific & 2003 & 28.16 & 5.31 & 14.56 & 20.43 & 26.41 & 66.61 \\
\hline health problem per month (U.S. dollars) & 2008 & 13.11 & 5.03 & 6.06 & 8.15 & 12.54 & 32.05 \\
\hline Inpatient out-of-pocket expenditure per year & 2003 & 136.93 & 70.62 & 91.28 & 114.64 & 108.53 & 274.90 \\
\hline (U.S. dollars) & 2008 & 68.68 & 24.63 & 34.57 & 66.36 & 88.38 & 129.96 \\
\hline Aggregated out-of-pocket expenditure on health & 2003 & 17.34 & 3.77 & 8.75 & 12.90 & 14.01 & 47.28 \\
\hline per month (U.S. dollars) & 2008 & 10.47 & 1.87 & 3.66 & 6.02 & 10.74 & 30.07 \\
\hline
\end{tabular}

Source: Life Quality Survey, 2003 and 2008, Cendex Calculations.

$\mathrm{CPI}$ : consumer price index, NEER: normal effective exchange rate.

is equal. With regard to the presence of chronic disease, there is a pro-rich index, although the health condition distribution for all quintiles seems to improve in 2008 for perception of bad health and presence of chronic disease.

Health insurance coverage shows impressive progress toward equity among populations. The rural CI indicators demonstrate equity attainment in social insurance with equal distribution among socioeconomic quintiles. The urban coverage share indicates a slight pro-rich advan- tage. The differences found in the equity indexes by insurance type illustrate the biased legal definition of the insurance regimens with a contributory plan affiliation geared toward the wealthiest and the formal sector of the economy, unlike the subsidized regimen, which focuses on the poor and informally employed. It is worth mentioning the generalized loss in participation across all socioeconomic quintiles in the contributive plan during the period analyzed. The opposite effect is found for the subsidized regimen.
The results for health service utilization indicate equity improvements in the use of all preventive and curative types of service. However, there is a wide gap in the proportion of health service utilization among the different quintiles. The poorest tend to use services less-preventive and curative as well as outpatient and inpatient. The very low use of dental preventive and medical specialist services by the lowest quintile is striking.

The HI for health service quality shows slight improvements in benefiting 
TABLE 4. Horizontal inequity index and differences, Colombia, 2003 and 2008

\begin{tabular}{|c|c|c|c|c|c|}
\hline & \multicolumn{2}{|c|}{2003} & \multicolumn{2}{|c|}{2008} & \multirow{2}{*}{$\begin{array}{l}\text { HI difference } \\
\text { 2008-2003 }\end{array}$} \\
\hline & $\mathrm{Cl}$ & $\mathrm{HI}$ & $\mathrm{Cl}$ & $\mathrm{HI}$ & \\
\hline \multicolumn{6}{|l|}{ Health condition } \\
\hline Less than good health status & $-0.1640^{a}$ & $-0.166^{a}$ & $-0.1556^{a}$ & $-0.1666^{a}$ & -0.0005 \\
\hline Presence of chronic illness & $0.0172^{b}$ & $0.0214^{a}$ & $0.0493^{a}$ & $0.0495^{a}$ & 0.0281 \\
\hline Days of sick leave & $-0.0529^{a}$ & -0.0131 & $-0.0462^{c}$ & -0.0239 & -0.0108 \\
\hline \multicolumn{6}{|l|}{ Social health insurance } \\
\hline Social health insurance coverage & $0.0960^{a}$ & $0.0934^{a}$ & $0.0191^{a}$ & $0.0180^{a}$ & -0.0754 \\
\hline Rural insurance coverage & $0.0149^{b}$ & $0.0162^{b}$ & 0.0026 & 0.0023 & -0.0139 \\
\hline Urban insurance coverage & $0.1001^{a}$ & $0.0983^{a}$ & $0.0234^{a}$ & $0.0227^{a}$ & -0.0756 \\
\hline Contributive plan affiliation & $0.2280^{a}$ & $0.2288^{a}$ & $0.3073^{a}$ & $0.3083^{a}$ & 0.0795 \\
\hline Subsidized plan affiliation & $-0.4724^{a}$ & $-0.4736^{a}$ & $-0.3521^{a}$ & $-0.3529^{a}$ & 0.1207 \\
\hline \multicolumn{6}{|l|}{ Health service use } \\
\hline Any preventive physician visit & $0.1442^{a}$ & $0.1450^{a}$ & $0.0906^{a}$ & $0.0913^{a}$ & -0.0537 \\
\hline Any preventive dentist visit & $0.2825^{a}$ & $0.2690^{a}$ & $0.2282^{a}$ & $0.2215^{\mathrm{a}}$ & -0.0475 \\
\hline Any curative visit & $0.0529^{a}$ & $0.0576^{a}$ & $0.0381^{a}$ & $0.0373^{a}$ & -0.0203 \\
\hline Any referral or visit to a specialist & $0.1412^{\mathrm{a}}$ & $0.1566^{a}$ & $0.0932^{a}$ & $0.1090^{a}$ & -0.0476 \\
\hline Any hospitalization & $0.0460^{a}$ & $0.0773^{a}$ & 0.0012 & $0.0361^{b}$ & -0.0412 \\
\hline \multicolumn{6}{|l|}{ Hospital service quality } \\
\hline $\begin{array}{l}\text { Perceived service quality of general } \\
\text { practitioner or specialist (less than good) }\end{array}$ & -0.0207 & 0.0038 & 0.0300 & $0.0595^{a}$ & 0.0557 \\
\hline $\begin{array}{l}\text { Perceived hospital service quality (less than } \\
\text { good) }\end{array}$ & $-0.1008^{a}$ & $-0.0822^{a}$ & 0.01786 & 0.04199 & 0.1242 \\
\hline Total or partial medicine supply & $0.0255^{b}$ & $0.0244^{b}$ & -0.0068 & -0.0069 & -0.0313 \\
\hline Waiting days: medical or dental visit & $0.1190^{a}$ & $0.1395^{a}$ & $0.0519^{b}$ & $0.0641^{a}$ & -0.0755 \\
\hline Waiting days: specialist visit & $-0.1441^{a}$ & $-0.1089^{a}$ & $0.0659^{c}$ & $0.0713^{b}$ & 0.1802 \\
\hline \multicolumn{6}{|l|}{ Health expenditure } \\
\hline $\begin{array}{l}\text { Contribution to social health insurance per } \\
\text { month }\end{array}$ & $0.2184^{a}$ & $0.2159^{a}$ & $0.2513^{a}$ & $0.2501^{a}$ & 0.0342 \\
\hline $\begin{array}{l}\text { Outpatient out-of-pocket expenditure for } \\
\text { specific health problem per month }\end{array}$ & $0.3741^{a}$ & $0.4186^{a}$ & $0.3973^{a}$ & $0.4081^{a}$ & -0.0105 \\
\hline Inpatient out-of-pocket expenditure per year & $0.2890^{a}$ & $0.3011^{a}$ & $0.3577^{a}$ & $0.3291^{a}$ & 0.0280 \\
\hline $\begin{array}{l}\text { Aggregated out-of-pocket expenditure on } \\
\text { health per month }\end{array}$ & $0.4217^{a}$ & $0.4752^{a}$ & $0.5167^{a}$ & $0.5374^{a}$ & 0.0622 \\
\hline
\end{tabular}

Source: Life Quality Survey, 2003 and 2008.

$\mathrm{Cl}$ : concentration index, $\mathrm{HI}$ : horizontal inequity index.

a $P<0.01$.

b $P<0.05$.

c $P<0.1$.

the poor population. In fact, standardized CIs of perceived hospital service quality and medicine supply demonstrate equity, without major differences among the socioeconomic groups for 2008. However, there is a fairly high perception of bad quality with significant deterioration in timely access to services. Waiting days for specialist visits improved for the poorest quintiles, while there is a relevant deterioration for the two wealthiest quintiles. It is important to highlight the improvement in access to medicines. This effect extends to all socioeconomic groups.

The health expenditure results indicate an unequal HI affecting the wealthiest population. The distribution by quintile indicates wide gaps between rich and poor quintiles both in contributions and in different types of out-of-pocket expenses. There is a clear tendency toward reduced out-of-pocket payments for outpatient and inpatient services be- tween 2003 and 2008. The aggregate outof-pocket expense also reported a significant reduction for 2008. These effects were relevant for all quintiles, although the reduction in out-of-pocket expenditure tends to be higher in the poorest populations.

The HI values, which are statistically significant, were decomposed into the contributions derived from non-need variables. Figure 1 shows the results from this process for both years analyzed. Household expenditure explains most of the inequalities for all health outcome variables.

Household expenditure, social health insurance, and education contribute to the unequal distribution in the positive perception of health status and health care utilization. Household expenditure, social health insurance, rural coverage, urban coverage, education, geographic region, and economic activity explain most of the pro-rich HI values. Marital status and socioeconomic strata have a significant effect on rural social insurance coverage.

Less than good perceived service quality for general practitioners or specialized doctors is explained mainly by occupation. The pro-rich concentration for medicine supply is associated with social health insurance for 2003 . The prorich $\mathrm{HI}$ for waiting days for medical or dental visits is related to social insurance and geographic region. A pro-rich deviation in specialist visits for 2008 is associated with private insurance. In contrast, this $\mathrm{HI}$ is related to geographic area for 2008. The health expenditure variables are mainly related to the household expenditure. These results are significant $(P<0.01)$.

\section{DISCUSSION}

Various studies in the scientific literature on health equity in Latin America 
FIGURE 1. Contribution of non-need variables to inequity (horizontal inequity index), Colombia, 2003-2008
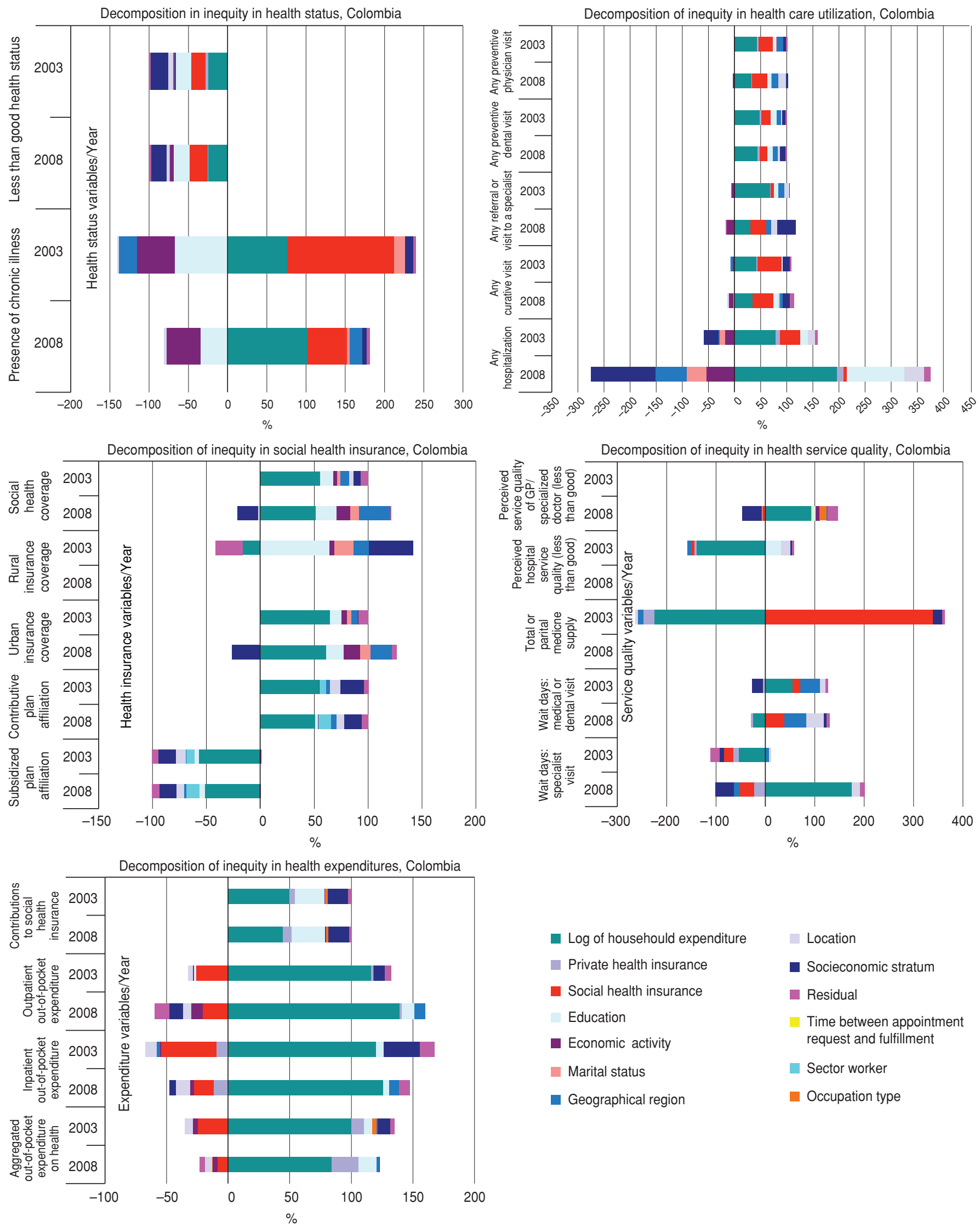

Log of househould expenditure
Private health insurance
Social health insurance
Education
Economic activity
Marital status
Geographical region

Location

- Socieconomic stratum

nesidual

Time between appointment request and fulfillment

Sector worker

Occupation type

GP: general practitioner. 
present different limitations in terms of their methodology and comparability among health systems. This difference explains current limitations in the conceptual and methodologic approaches in measuring equity (21).

Furthermore, there is an attribution issue: what effect may health systems have on final mortality and health conditions? System arrangements seeking access efficiency may take long periods to effect changes in coverage and improve health status. Time windows may be different for the accurate evaluation of such effects. This difference can lead to biased conclusions about system effectiveness $(4,22)$. It is important to understand the contribution of socioeconomic and needs factors in generating equity from health systems.

Like other studies carried out in Latin America $(23,24)$, those conducted in Colombia (25) do not confront the horizontal equity issue. Most studies measure differences in health variables without addressing the need condition. Therefore, they do not formally estimate inequity.

This study design established the relation of such socioeconomic conditions, the needs conditions, and a set of variables that will estimate the results of the Colombian system in terms of health, insurance, access, quality, and out-of-pocket expenditures. The time window analyzed (2003-2008) evinces the biggest expansion in social insurance coverage. This growth was enabled by the government's investment in expanding the subsidized regimen. It is possible that results capture the effects in coverage and access to ambulatory services. The effects on access for inpatients, out-of-pocket expenses, quality of health services, and health status could take some time to be realized.
Unlike the extensive qualitative evidence available with regard to negative perceptions about the reform, this study's results evidence significant progress in terms of access to service and financial protection beyond the issue of universal insurance coverage. Both the CI breakdown and changes in the relative share of the poorest segment of the population point to relevant progress in equity goals set forth by the 1993 health reform. However, the negative results in terms of perception of quality and timely access to service imply possible constraints in the future.

The results raise questions about whether the service structure will have the capacity to support insurance expansion in the short term while maintaining the equity levels reached. Another critical aspect relates to the trade-off between the contributory and subsidized regimens in dual operation conditions. This characteristic concerns differences in the private contributory scheme and the quasi-public subsidized regimen. Results indicate a potential crowding out from the subsidized to the contributory scheme, which may be expressed as the reduction in contributive share for the higher-income population. This type of effect has been analyzed in the health system context (26, 27). However, it raises questions about incoming changes in the subsidized regimen with regard to socioeconomic and demographic issues. The progressivity of taxes and contributions could have changed because of increase enrollment of rich people in the subsidized regimen.

The results of the study also highlight the need for thorough regulatory monitoring and adjustment of the system, with an emphasis on analysis of the rela-

\section{REFERENCES}

1. Velandia F, Corral L, Talero R, Valencia A, Serna E. Financiamiento. In: Yepes F, ed. La salud en Colombia. Estudio sectorial de salud, Vol. II. Bogotá: Departamento Nacional de Planeación, Ministerio de Salud; 1999. Pp. 81-259.

2. Pabón H, Combat G, Villota J. Infraestructura. In: Yepes F, ed. La salud en Colombia. Estudio sectorial de salud. Bogotá: Departamento Nacional de Planeación, Ministerio de Salud; 1990. Pp. 321-418.

3. Garavito L. Evaluación y propuesta de ajuste a la operación del Régimen Subsidiado Colombiano y Acuerdo 415 de 2009. Bogotá: Ministerio de la Protección Social; 2009.

4. Esteves RJF. The quest for equity in Latin America: a comparative analysis of the health care reforms in Brazil and Colombia. Int J Equity Health. 2012;11(6).

5. Trujillo AJ. Medical care use and selection in a social health insurance with an equalization fund: evidence from Colombia. Health Econ. 2003;12(3):231-46.

6. O'Meara G, Ruiz F, Amaya J. Impacto del aseguramiento sobre uso y gasto en salud en Colombia. Bogotá: Centro de Proyectos para el Desarrollo, Cendex, Pontificia Universidad Javeriana; 2001.

7. Ruiz F, Amaya L, Venegas S. Progressive segmented health insurance: Colombia health Econ. 2007;16(1):3-18. reform and access to health services. Health tion between growth and coverage and the benefits promised to the population. This factor implies the effective availability of human and institutional resources. Further studies must address supply capacity and the ability to cope with the increased demand for health services derived from health plan equalization implemented in 2012. These Colombian reform results may become relevant for developing and adjusting other systems that have adopted the objective of universal coverage and guaranteed institutionalized population rights and may include the growth of private providers as a strategy to expand coverage.

The main limitations of this study are related to restrictions on the data used. The strengths of the methodology are the comparability and the use of comprehensive indicators toward equity differences among socioeconomic groups. New studies should emphasize the need and non-need variables used in decomposition of the CI.

Acknowledgments. The authors thank Gisele Almeida, Rolando Enrique Peñaloza Quintero, Julia Isabel Eslava, Lucia Mina, Brandon Berger, and the anonymous reviewers for their interesting comments; Diana Carolina Vargas Castro for her editing collaboration; and Edris Joy Bourdeau for the English version.

Funding. This study was funded by the Equity in Health Systems in Latin America and the Caribbean (EquiLAC) Project of the Pan American Health Organization.

\section{Conflict of interest. None}

8. Giedion U, Uribe MV. Colombia's universal health insurance system. Health Aff (Millwood). 2009;28(3):853-63.

9. Amaya JL, Ruiz F. Determining factors of catastrophic health spending in Bogota, Colombia. Int J Health Care Finance Econ. 2011; 11(2):83-100.

10. Ruiz F, Quiroga A. Social health insurance and universal coverage: effects of fragmented risk pooling on effective health services consumption. J Health Econ. Forthcoming 2013.

11. Trujillo AJ, Vecino AI, Ruiz F, Steinhardt LC. Health insurance doesn't seem to discourage prevention among diabetes patients in Colombia. Health Aff (Millwood). 2010;29(12): 2180-8. 
12. Vargas JF. Políticas públicas universales o focalizadas: ventajas y desventajas. El caso del SISBEN en Colombia [mimeo]. Bogotá: Universidad de los Andes; 2000.

13. Homedes N, Ugalde A. Why neoliberal health reforms have failed in Latin America. Health Policy. 2005;71(1):83-96

14. Suárez BRM. Policy tools for achieving more equitable financing of access to health care services in Latin America and the Caribbean. Rev Panam Salud Publica. 2002;11(5-6):418-24.

15. Abadía CE, Oviedo DG. Itinerario burocrático en Colombia. Una herramienta teórica y metodológica para evaluar los sistemas de salud basados en la atención gerenciada. Soc Sci Med. 2009;68:1160-3.

16. Ruiz F, Uprimny M. Sistema de salud y aseguramiento social entre la reforma estructural y el ajuste regulatorio. Bogotá: Ecoe Ediciones; 2012.

17. Van Doorslaer E, Masseria C. Income-related inequality in the use of medical care in 21 OECD countries. Paris: Organisation for Economic Co-operation and Development; 2004. (Health Working Papers)
18. Lu JFR, Leung GM, Kwon S, Tin KY, Van Doorslaer E, O'Donnell O. Horizontal equity in health care utilization evidence from three high-income Asia economies. Soc Sci Med. 2007;64(1):199-212.

19. Almeida G, Sarti FM. Measuring evolution of income-related inequalities in health and health care utilization in selected Latin American and Caribbean countries. Rev Panam Salud Publica. 2013;33(2):83-9.

20. O'Donnell O, Van Doorslaer E, Wagstaff A, Lindelow M. Analyzing health equity using household survey data. Washington, D.C.: World Bank Institute; 2008.

21. Gómez R. La mortalidad evitable como indicador de desempeño de la política sanitaria Colombia, 1985-2001. Medellín: Revista Facultad Nacional de Salud Pública, Universidad de Antioquia; 2006.

22. Wallace S, Gutierrez V. Equity of access to health care for older adults in four major Latin American cities. Rev Panam Salud Publica. 2005;17(5-6):394-409.

23. Noronha K, Viegas M. Desigualdades sociais em saúde e na utilizaçao dos serviços de saúde entre os idosos na América Latina. Rev Panam Salud Publica. 2005;14(5-6):410-8.

24. Hernández M. Reforma sanitaria, equidad y derecho a la salud en Colombia. Cad Saude Publica. 2002;18(4):991-1001.

25. Cutler D, Gruber J. Does public insurance crowd out private insurance. Q J Econ. 1996; 391-430.

26. Sloan FA, Norton EC. Adverse selection, bequests, crowding out and private demand for insurance: evidence from the long-term care insurance market. J Risk Uncertain. 1997;15: 201-19.

27. Yazici EY, Kaestner R. Medicaid expansions and the crowding out of private health insurance. Cambridge, Massachusetts: National Bureau of Economic Research; 1998. (Working Paper 6527).

Manuscript received on 7 March 2012. Revised version accepted for publication on 19 December 2012.

RESUMEN Objetivo. Evaluar la evolución de la equidad en el sistema de salud colombiano, según cinco dimensiones: condición de salud, cobertura del seguro social de salud, utilización de los servicios de salud, calidad y gasto en salud.

Análisis de la equidad en cinco dimensiones del sistema de salud de Colombia, 2003-2008

Palabras clave
Métodos. Se utilizó una metodología común de estandarización para evaluar la equidad en países del continente americano. Los datos se tomaron de la Encuesta de Calidad de Vida de 2003 y 2008. Después de la estandarización indirecta se estimaron los índices de concentración y de inequidad horizontal. Se aplicó un análisis de descomposición; se estimó el nivel de vida a partir del gasto agregado mensual del hogar por adulto equivalente.

Resultados. La equidad aumentó notablemente con respecto a la afiliación al seguro social de salud, el acceso a los servicios médicos y curativos, y la percepción de la calidad del servicio de atención sanitaria. Persisten aún considerables brechas, que afectan a las poblaciones más pobres, especialmente en su percepción de tener problemas de salud y su acceso a servicios preventivos médicos y odontológicos.

Conclusiones. Se requiere avanzar en la aplicación de las estrategias de salud pública preventivas en Colombia para afrontar el aumento de la demanda ocasionado por la mayor cobertura del seguro social. Debe mejorarse el acceso de la población a servicios integrales en los casos de enfermedades crónicas y a servicios de salud bucodental, y los planes de beneficios deben integrarse sin afectar a los logros en equidad ya registrados. Las inequidades se explican mejor por las variables socioeconómicas que por los factores relacionados con la salud.

Equidad en salud; sistemas de salud; equidad en el acceso; economía de la salud; política de salud; Colombia. 
REVISTA

PANAMERICANA

DE SALUD PÚBLICA
PAN AMERICAN

JOURNAL OF

PUBLIC HEALTH

Material suplementario / Supplementary material / Material supplementar

Supplementary material to:

Scott E, Theodore K. Measuring and explaining health and health care inequalities in Jamaica, 2004 and 2007. Rev Panam Salud Publica. 2013;33(2):116-21.

This material formed part of the original submission and has been peer reviewed. We post it as supplied by the authors. 
CURVE 1. Concentration curves for standardized health status variables, Jamaica, 2007.

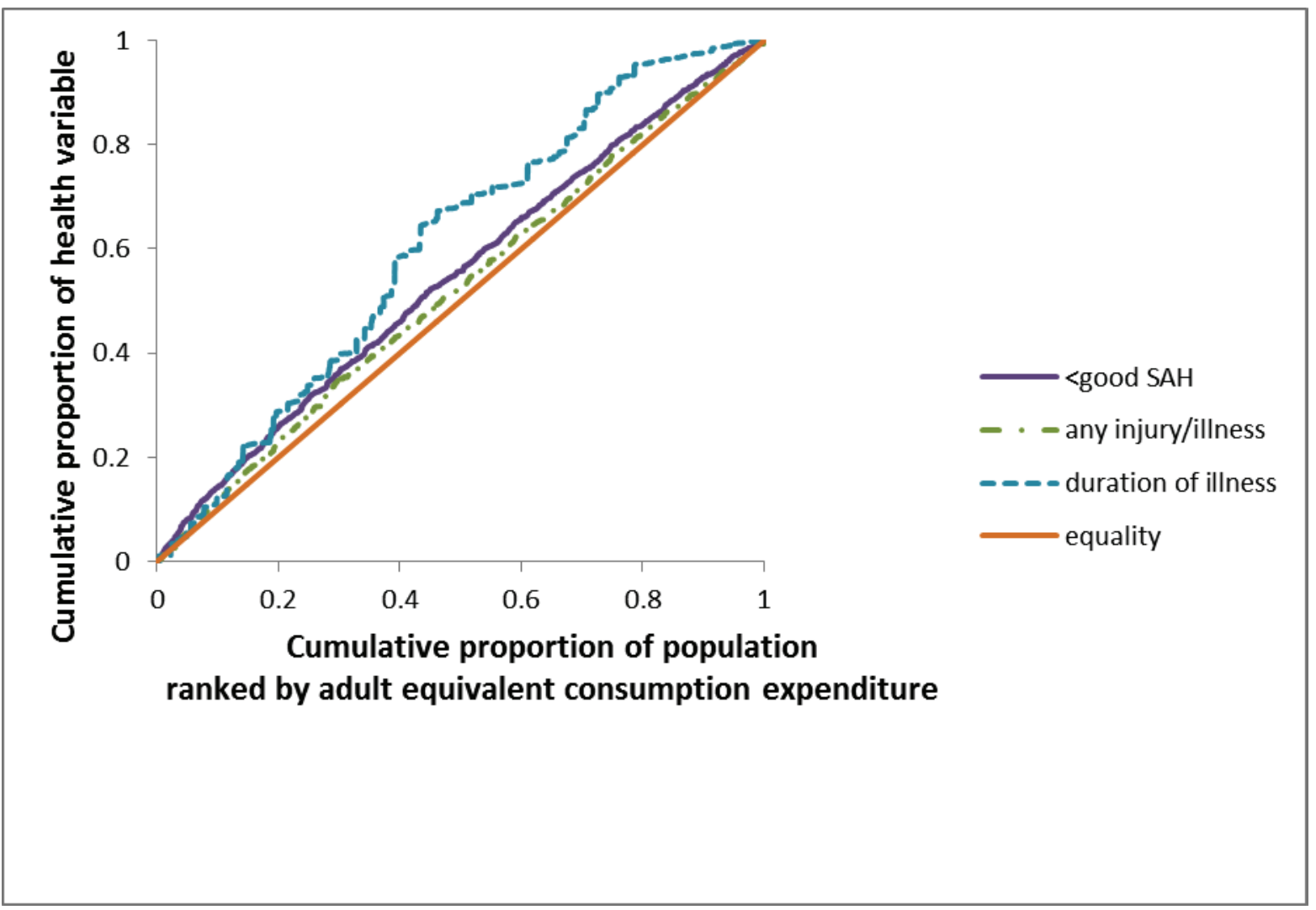


CURVE 2. Concentration curves for standardized health care utilization variables, Jamaica, 2007.

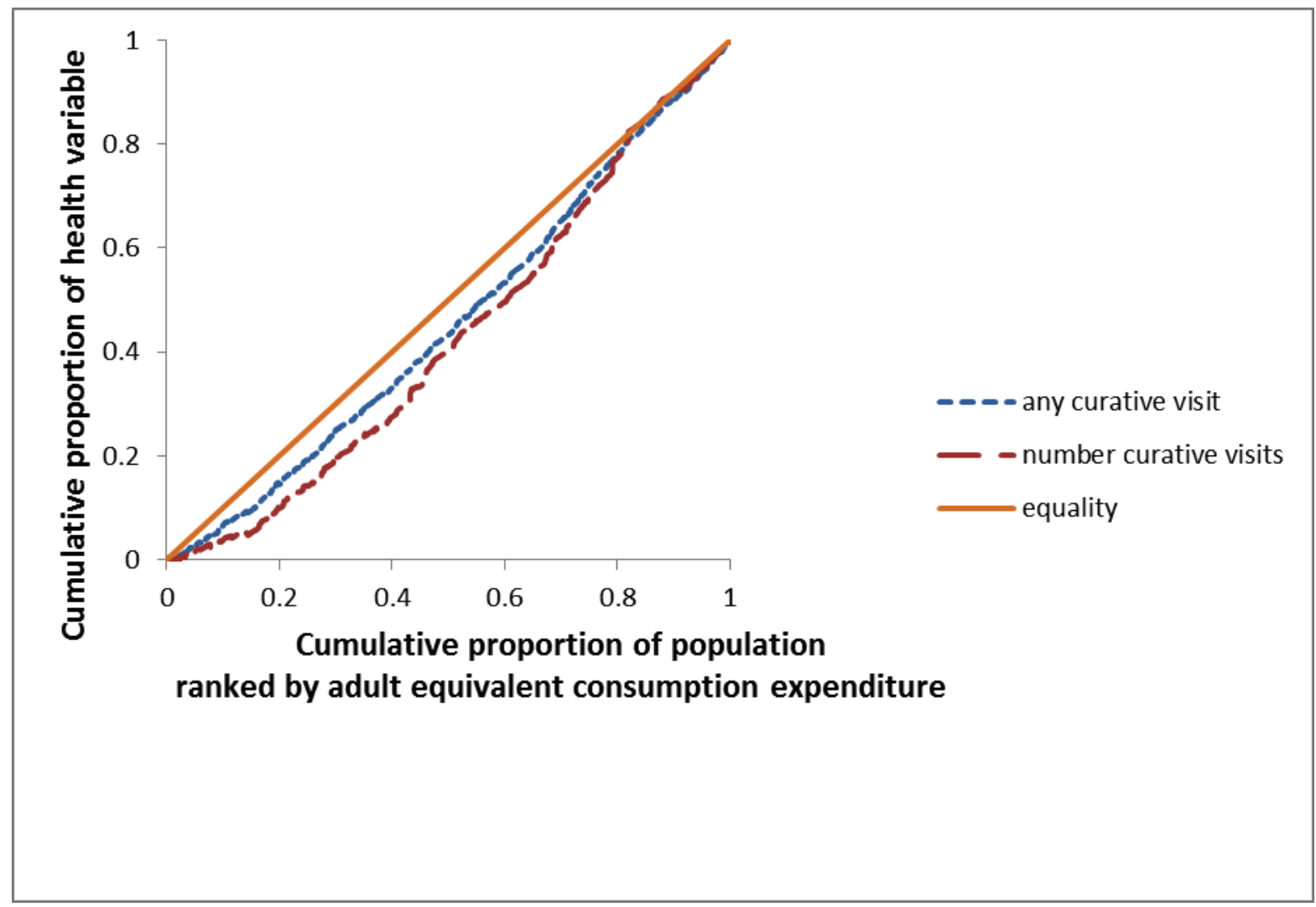

